\title{
CONTROL OF OVULATION IN CATTLE WITH MELENGESTROL ACETATE
}

\author{
II. EFFECTS ON FOLLICULAR SIZE AND ACTIVITY
}

\author{
R. G. ZIMBELMAN AND L. W. SMITH \\ Agricultural Division, The Upjohn Company, Kalamazoo, Michigan, U.S.A.
}

(Received 2nd June 1965)

\begin{abstract}
Summary. The effects of oral melengestrol acetate (MGA) on ovarian activity have been studied in 264 dairy and beef heifers. A total of ninety-eight heifers received $0.4 \mathrm{mg}$ of MGA daily for short periods of time (18 to 32 days) and ovarian activity was determined by rectal palpation. As the incidence of a detectable corpus luteum decreased from $76 \%$ to $10 \%$, the incidence of a detectable follicle increased from $56 \%$ to $91 \%$. Follicular size also increased with time. Samples of cervical mucus were rated according to fern pattern, which was interpreted as due to an oestrogenic influence, and which occurred upon regression of the corpus luteum even though oestrus and ovulation were inhibited by MGA treatment.

A total of 166 beef heifers was used in long-term studies (105 to 116 days) of MGA treatment. Significant $(P<0.05)$ increases were found in the weight of follicular fluid, primarily of the largest follicle from the pair of ovaries. Also indicative of increased oestrogenicity was an increased adrenal weight in puberal, intact MGA-treated heifers. The adrenal weights of spayed heifers tended to decrease with MGA treatment. The optimal dose for increased follicular activity appears to be near $0.4 \mathrm{mg}$ MGA daily/heifer.
\end{abstract}

\section{INTRODUCTION}

A recent review of studies concerned with the synchronization of ovarian cycles in cattle and sheep indicated that there have been no reports on studies in ewes and cows on the mode of action of oral progestagens (Lamond, 1964). The present paper represents one of a planned series of publications describing studies of this nature with melengestrol acetate (MGA) in cattle. A preceding paper discussed the effects of dosage and route of administration (Zimbelman \& Smith, 1966). The present paper describes follicular status and evidences of increased oestrogenic secretion during treatment.

\section{METHODS}

In the first phase of this study, four groups (ninety-eight head) of heifers, having normal ovarian and oestrous cycles, were used (Trial A-Table 1). A grain ration containing $0.4 \mathrm{mg} \mathrm{MGA} /$ heifer was fed daily for periods of time 
ranging from 18 to 32 days. Heifers received their first treatment as a group on the same day, thus all stages of the oestrous cycle were represented. Ovarian status was determined at frequent intervals by rectal palpation of all heifers. Cervical mucus samples were taken from two groups with a plastic insemination pipette during predesignated palpations. The samples were collected from heifers beginning at 8 or more days after the start of MGA treatment and at intervals until ovulation had occurred. The mucus samples were rated according to a previously described procedure (Alliston, Patterson \& Ulberg, 1958) based on the degree of the ferning pattern present in dried smears. Data on these four groups of heifers have been combined for brevity.

TABLE 1

DESIGN OF STUDIES TO DETERMINE EFFECT OF MGA TREATMENT ON FOLLICULAR ACTIVITY

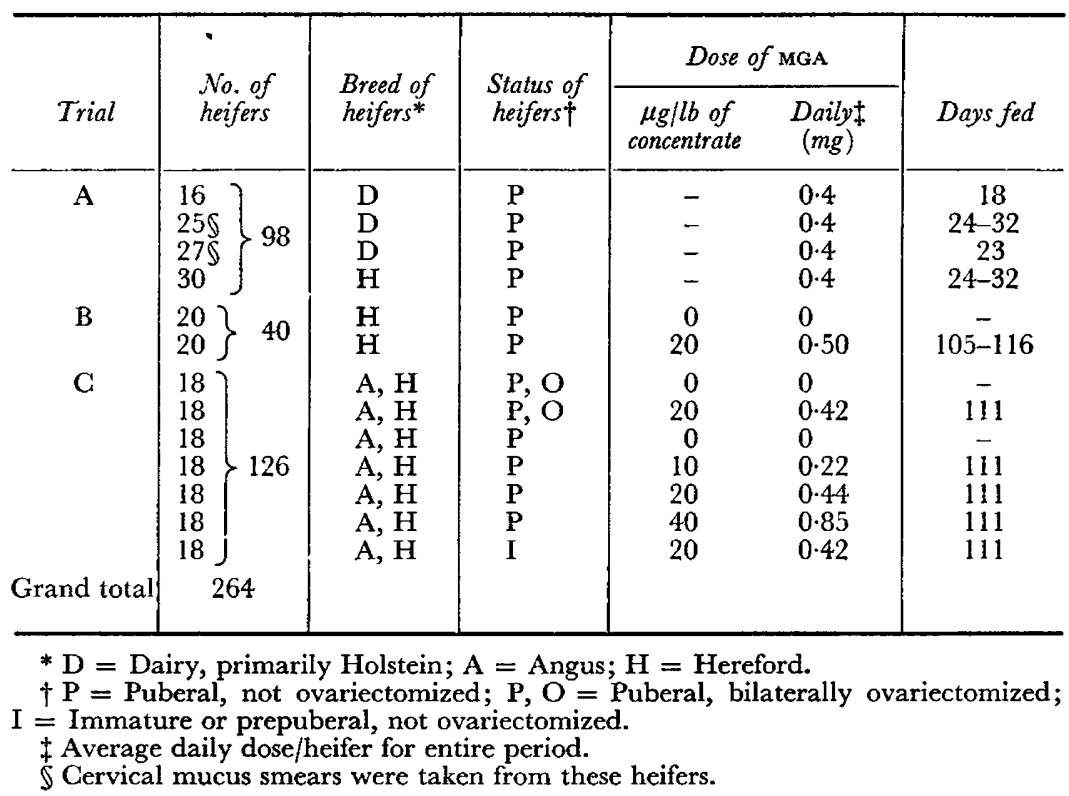

Two trials were presented in the second phase of the study. In Trial B, there were two groups of twenty heifers each (Table 1). A control group received a mixed concentrate ration ad libitum in addition to a small amount of hay daily, while the treated group received the same concentrate ration containing $20 \mu \mathrm{g}$ of MGA/pound. The average daily intake of MGA for this group of heifers was $0.50 \mathrm{mg} /$ animal daily. Only heifers which were known to be puberal were used in this study. All heifers were weighed and the reproductive organs palpated per rectum at 2-week intervals from the start of treatment for 14 weeks. Five heifers from each group were slaughtered at 106, 110, 113 and 117 days from the start of treatment. Treatment continued until $24 \mathrm{hr}$ before slaughter. At slaughter, the adrenal glands, ovaries and uterus were removed for study.

In Trial $\mathrm{C}$ of the second phase, there were seven groups of eighteen animals each with nine heifers of two breeds. Of these, six groups were considered 
puberal, based on the palpation of a detectable corpus luteum before the start of treatment. The remaining group of heifers did not have a detectable corpus luteum at any of three consecutive weekly palpations immediately before treatment, thus they were considered as prepuberal. Two of the groups considered as puberal were spayed by supravaginal laparotomy at 11 to 13 days before the start of treatment.

One intact and one spayed group of puberal heifers were fed a mixed concentrate ration ad libitum plus a small amount of hay. The remaining groups received the same concentrate ration medicated with 10,20 or $40 \mu \mathrm{g}$ of $\mathrm{MGA} / \mathrm{lb}$. The average daily intake was about $0.22,0.43$ and $0.85 \mathrm{mg}$ of $\mathrm{MGA} / \mathrm{head}$ daily for the three levels, respectively. Treatment continued for 111 days and six of eighteen heifers from each group were slaughtered at 112 days from the start of treatment. The twelve remaining heifers were switched to the unmedicated concentrate ration until slaughtered at 114 or 119 days. Thus one-third of each treated group was slaughtered at 1, 3 or 8 days after last feeding (ALF) of MGA. Rectal palpation and collection of tissues were similar to Trial B.

Statistical analyses were performed using $\chi^{2}$ or analysis of variance where applicable. The analysis of variance of Trial $\mathrm{C}$ considered these main effects: breed, treatment and slaughter date. When mean squares due to interactions were not significantly $(P>0 \cdot 10)$ different from the error mean square, the sums of squares and degrees of freedom were pooled. The magnitude of difference required for significance between any two main effect classifications was determined by the method of Snedecor (1956).

Follicular fluid weights were determined by first weighing the intact, trimmed ovaries of each animal. In Trials B and $\mathrm{C}$, the largest follicle was punctured and the ovary was re-weighed after removal of the follicular fluid. The ovary was then sliced with a special device holding razor blades at $5 \mathrm{~mm}$ intervals and the difference between the weight after slicing and blotting of fluid and the weight before puncturing the largest follicle was considered as total follicular fluid. In Trial C, the corpus luteum was also removed to allow comparisons of the non-luteal portion of the ovary.

\section{RESULTS}

A corpus luteum was detected by rectal palpation in about $75 \%$ of the treated heifers in Trial A at the beginning of treatment or at about the 1st week (Table 2). After 2 weeks of treatment, the incidence of a detectable corpus luteum decreased to $47 \%$ with a further decrease to $10 \%$ by 3 weeks. Of eight detectable corpora lutea at 22 to 24 days, five formed from an ovulation during treatment. These results confirm previous data indicating that $0.4 \mathrm{mg}$ MGA daily effectively inhibited ovulation in most heifers. The percentage of animals with a follicle detected by rectal palpation increased from $55 \%$ at about the 1st week of treatment to $74 \%$ by the 2 nd week and to $91 \%$ by 22 to 24 days of treatment. The average size of the largest palpable follicle increased gradually from $13.7 \mathrm{~mm}$ at the start of treatment to $16.3 \mathrm{~mm}$ at about 3 weeks.

Follicular size cannot always be assumed to be a reflection of a follicular activity, such as oestrogen production. Upon regression of the corpora lutea, 
gross appearance of the heifers revealed signs usually associated with the period of oestrus, namely swelling of external genitalia and copious discharges of mucus from the vagina. Such heifers demonstrated interest in mounting other heifers, but would not stand to be mounted by other animals. Smears were made from

TABLE 2

OVARIAN STATUS OF HEIFERS RECEIVING $0.4 \mathrm{mg}$ MGA DAILY

\begin{tabular}{l|c|c|c|c}
\hline & \multicolumn{4}{|c}{ Days of treatment when palpated } \\
\cline { 2 - 5 } & 0 to 1 & 8 to 9 & 13 to 15 & 22 to 24 \\
\hline $\begin{array}{l}\text { Number of heifers } \\
\text { Palpated* }\end{array}$ & 98 & 98 & 98 & $82^{*}$ \\
$\quad \begin{array}{l}\text { With follicles } \\
\text { Corpus luteum } \\
\text { Incidence (\%) } \dagger\end{array}$ & 55 & 54 & 73 & 75 \\
$\begin{array}{l}\text { Follicles } \\
\text { Incidence (\%) } \dagger\end{array}$ & 56 & 75 & $47 \S$ & $10 \uparrow$ \\
Size & 13.7 & 55 & 74 & 91 \\
\hline
\end{tabular}

* Only three of four groups fed for 22 days or greater-Trial A.

$\dagger$ Percentage of heifers palpated with a palpable corpus luteum or follicle.

$\ddagger$ Estimated average size $(\mathrm{mm})$ of largest follicle/heifer.

$\$$ Of forty-six corpora lutea, two were from ovulation during treatment.

If Of eight corpora lutea, five were from ovulation during treatment.

\section{TABLE 3}

CERVICAL MUGUS SMEAR RATINGS OF HEIFERS AS INFLUENGED BY THE CORPUS LUTEUM AND ORAL MGA TREATMENT

\begin{tabular}{|c|c|c|c|c|c|}
\hline \multirow{2}{*}{$\begin{array}{l}\text { Mucus } \\
\text { smear } \\
\text { ratings }\end{array}$} & \multicolumn{2}{|c|}{ During MGA treatment } & \multicolumn{3}{|c|}{ Following MGA treatment } \\
\hline & $\begin{array}{c}\text { Corpus } \\
\text { luteum } \\
\text { present }(\%)\end{array}$ & $\begin{array}{c}\text { Corpus* } \\
\text { luteum } \\
\text { regressed }(\%)\end{array}$ & $\begin{array}{c}\text { All } \\
\text { smears }(\%)\end{array}$ & $\begin{array}{c}\text { Prior to } \\
\text { oestrus }(\%)\end{array}$ & $\begin{array}{c}\text { Prior to } \ddagger \\
\text { ovulation }(\%)\end{array}$ \\
\hline $\begin{array}{l}1 \text { or } 2 \\
3 \text { or } 4 \\
5 \text { or } 6\end{array}$ & $\begin{array}{r}83 \\
17 \\
0\end{array}$ & $\begin{array}{l}28 \\
47 \\
25\end{array}$ & $\begin{array}{l}13 \\
52 \\
36\end{array}$ & $\begin{array}{l}11 \\
50 \\
39\end{array}$ & $\begin{array}{l}15 \\
54 \\
31\end{array}$ \\
\hline No. of smears & 41 & 128 & 64 & 38 & 26 \\
\hline$\chi^{2}$ & \multicolumn{2}{|c|}{$39.78(P<0.005)$} & $52(P<0.05)$ & $0 \cdot 60$ & \\
\hline
\end{tabular}

* Corpus luteum defined as regressed when size was $4 \mathrm{~mm}$ smaller than previous or no longer palpable.

$\dagger$ Cervical mucus was collected near the time of approaching oestrus, but prior to observed oestrus.

$\ddagger$ Cervical mucus samples taken after oestrus was observed but prior to ovulation.

169 samples during MGA treatment and were classified as to whether the corpus luteum was present or had regressed. Regression for this purpose was defined as no longer palpable or more than $4 \mathrm{~mm}$ smaller than the estimated size at the previous palpation. Ratings of 1 or 2 indicate little if any fern pattern and represented $83 \%$ of the smears taken in the presence of the corpus luteum, but 
only $28 \%$ of those with the corpus luteum regressed. Ratings of 3 or 4 indicate typical fern patterns over less than the entire area, and the incidence of this finding increased from $17 \%$ with the corpus luteum present to $47 \%$ after regression of the corpus luteum. Fern patterns over the entire area of the smear are rated as 5 or 6 and were found to make up $25 \%$ of the smears after corpus luteum regression. A $\chi^{2}$ analysis of the data revealed that the distribution of smear ratings differed significantly. These data were interpreted to indicate an increased oestrogenic activity of the follicles which appeared during MGA treatment upon regression of the corpus luteum.

TABLE 4

OVARIAN STATUS OF HEIFERS DURING LONG-TERM ORAL MGA TREATMENT

\begin{tabular}{|c|c|c|c|c|c|c|c|c|c|c|}
\hline \multirow[b]{2}{*}{ Trial } & \multirow{2}{*}{$\begin{array}{l}\text { No. of } \\
\text { heifers }\end{array}$} & \multirow{2}{*}{$\begin{array}{c}\text { Dose of } \\
\text { MGA }\end{array}$} & \multirow{2}{*}{$\begin{array}{c}\text { Pre- } \\
\text { trealment }\end{array}$} & \multicolumn{7}{|c|}{ Weeks of treatment } \\
\hline & & & & 2 & 4 & 6 & 8 & 10 & 12 & 14 \\
\hline \multirow{3}{*}{ B } & & & \multicolumn{8}{|c|}{ Incidence of detectable corpus luteum $(\%)$} \\
\hline & 20 & & & 80 & 85 & 85 & 65 & 60 & 85 & 80 \\
\hline & 20 & $0 \cdot 50$ & 73 & 10 & 0 & 0 & 0 & 0 & 0 & 0 \\
\hline \multirow[t]{6}{*}{$\mathrm{C}$} & 18 & 0 & 64 & 72 & 67 & 57 & 89 & 67 & 61 & 72 \\
\hline & 18 & 0.22 & 66 & 57 & 22 & 22 & 28 & 28 & 28 & 33 \\
\hline & 18 & 0.44 & 66 & 33 & 6 & 0 & 0 & 6 & 0 & 6 \\
\hline & 18 & $0 \cdot 85$ & 67 & 11 & 0 & 0 & 0 & 0 & 0 & 0 \\
\hline & $18^{*}$ & $0 \cdot 42$ & $0^{*}$ & 0 & 0 & 0 & 0 & 0 & 0 & 6 \\
\hline & & & \multicolumn{8}{|c|}{ Incidence of detectable follicle (\%) } \\
\hline \multirow[t]{2}{*}{ B } & 20 & 0 & & 55 & 45 & 20 & 30 & 50 & 25 & 25 \\
\hline & 20 & 0.50 & 20 & 90 & 100 & 100 & 100 & 100 & 100 & 100 \\
\hline \multirow[t]{6}{*}{ C } & 18 & 0 & 35 & 17 & 44 & 44 & 28 & 28 & 33 & 33 \\
\hline & 18 & $0 \cdot 22$ & 43 & 67 & 67 & 72 & 67 & 61 & 78 & 57 \\
\hline & 18 & 0.44 & 38 & 67 & 94 & 100 & 100 & 94 & 100 & 89 \\
\hline & 18 & $0 \cdot 85$ & 35 & 61 & 94 & 94 & 100 & 100 & 100 & 94 \\
\hline & $18^{*}$ & 0.42 & & 72 & 78 & 100 & 94 & 94 & 100 & 100 \\
\hline & & & \multicolumn{8}{|c|}{ Size of largest detectable follicle $(\mathrm{mm}) \uparrow$} \\
\hline \multirow[t]{2}{*}{ B } & 20 & 0 & & 14 & 15 & 12 & 13 & 14 & 15 & 14 \\
\hline & 20 & 0.50 & 14 & 15 & 18 & 17 & 17 & 16 & 18 & 18 \\
\hline \multirow[t]{5}{*}{ C } & 18 & & 15 & 12 & 14 & 13 & 12 & 14 & 14 & 14 \\
\hline & 18 & $0 \cdot 22$ & 15 & 14 & 15 & 17 & 16 & 17 & 17 & 16 \\
\hline & 18 & 0.44 & 14 & 13 & 16 & 17 & 18 & 17 & 17 & 16 \\
\hline & 18 & 0.85 & 14 & 13 & 15 & 14 & 14 & 16 & 16 & 15 \\
\hline & $18^{*}$ & 0.42 & 12 & 12 & 14 & 14 & 16 & 16 & 16 & 15 \\
\hline
\end{tabular}

* Were not puberal at start of treatment.

$\dagger$ Mean of estimated follicle sizes to nearest whole number.

At the end of MGA treatment, additional mucus samples were obtained beginning near the time of expected oestrus. There was no significant difference between smears taken before oestrus and those taken after oestrus and ovulation as determined by rectal palpation. All sixty-four samples taken following MGA treatment were compared with those (128) taken during MGA treatment with the corpus luteum regressed. There was a further shift from $28 \%$ with little or no pattern to only $13 \%$ in this category (1 or 2), and an increase from $25 \%$ to $36 \%$ of the smears with typical fern patterns over the entire area ( 5 or 6$)$. This additional increase in fern patterns is in agreement with the interpretation of a relationship of fern patterns to oestrogenic influence. 
The heifers on long-term oral MGA treatment also confirmed that doses above $0.4 \mathrm{mg}$ daily were effective in inhibiting ovulation. At $0.22 \mathrm{mg}$ daily, the percentage of animals with a corpus luteum ranged from $22 \%$ to $33 \%$ during 4 to 14 weeks of treatment, compared with $57 \%$ to $89 \%$ for control animals. This indicates a partial inhibition of ovulation. The percentage of animals with a detectable follicle ranged from $17 \%$ to $55 \%$ at various times in control groups, from $57 \%$ to $78 \%$ with partial inhibition of ovulation $(0.22 \mathrm{mg}$ daily), and from $78 \%$ to $100 \%$ for groups $(0.42$ to $0.85 \mathrm{mg}$ daily) with almost complete inhibition of ovulation. Follicular size of puberal heifers was greater at each 2-week period during which ovulation was inhibited with MGA. Follicular size for the immature heifers $(0.42 \mathrm{mg})$ was less than the follicular size of comparable puberal heifers $(0.44 \mathrm{mg})$ but the difference narrowed with time.

\section{TABLE 5}

OVARIAN WEIGHTS OF HEIFERS FOLLOWING LONG-TERM ORAL MGA TREATMENT

\begin{tabular}{|c|c|c|c|c|c|c|}
\hline \multirow[b]{2}{*}{ Trial $\uparrow$} & \multirow[b]{2}{*}{ MGA dose } & \multicolumn{3}{|c|}{ Ovarian weight $(\mathrm{g})$} & \multicolumn{2}{|c|}{ Follicular fuid $(\mathrm{g})$} \\
\hline & & Total intact & $\begin{array}{c}\text { Minus } \\
\text { corpus luteum }\end{array}$ & $\begin{array}{l}\text { After } \\
\text { slicing }\end{array}$ & $\begin{array}{l}\text { Largest } \\
\text { follicle }\end{array}$ & Total \\
\hline B & $\begin{array}{l}0 \\
0.50 \\
\quad D S\end{array}$ & $\begin{array}{r}13 \cdot 30 \\
13 \cdot 27 \\
2 \cdot 63\end{array}$ & $\begin{array}{l}- \\
- \\
-\end{array}$ & $\begin{array}{l}11 \cdot 34 \\
8 \cdot 15^{*} \\
2 \cdot 17\end{array}$ & $\begin{array}{l}1 \cdot 08 \\
3 \cdot 93^{*} \\
0 \cdot 97\end{array}$ & $\begin{array}{l}1.96 \\
5 \cdot 12^{*} \\
1 \cdot 30\end{array}$ \\
\hline $\mathrm{C}$ & \begin{tabular}{l}
0 \\
0.22 \\
0.44 \\
0.85 \\
$0.42+$ \\
\multicolumn{1}{c}{ D\$ }
\end{tabular} & $\begin{array}{c}13 \cdot 82^{\mathrm{a}}, \mathrm{b} \\
13 \cdot 32^{\mathrm{a}}, \mathrm{b} \\
15 \cdot 96^{\mathrm{b}} \\
12 \cdot 44^{\mathrm{a}} \\
12 \cdot 09^{\mathrm{a}} \\
3 \cdot 34\end{array}$ & $\begin{array}{l}10 \cdot 54^{\mathrm{a}} \\
11 \cdot 97^{\mathrm{a}, \mathrm{b}} \\
13 \cdot 84^{\mathrm{b}} \\
12 \cdot 04^{\mathrm{a}} \text {, b } \\
11 \cdot 10^{\mathrm{a}, \mathrm{b}} \\
3 \cdot 31\end{array}$ & $\begin{array}{l}8.68 \\
8.73 \\
8.72 \\
7.96 \\
6 \cdot 74 \\
2.07\end{array}$ & $\begin{array}{l}0.95^{\mathrm{a}} \\
1.99^{\mathrm{a}}, \mathrm{b} \\
3.36^{\mathrm{b}} \\
3.01^{\mathrm{b}} \\
2.87^{\mathrm{b}} \\
1.63\end{array}$ & $\begin{array}{l}1 \cdot 86^{\mathrm{a}} \\
3 \cdot 24^{\mathrm{a}, \mathrm{b}} \\
5 \cdot 11^{\mathrm{a}} \\
4 \cdot 08^{\mathrm{a}} \\
4 \cdot 36^{\mathrm{a}} \\
1 \cdot 93\end{array}$ \\
\hline
\end{tabular}

* Significantly $(P<0.05)$ different from untreated controls.

+ See Table 4 for No. of animals/group.

$¥$ Were not puberal at start of treatment.

$\delta \mathrm{D}=$ Magnitude of difference required for statistical significance $(P<0.05)$ between two means.

(a and b) All means bearing the same superscript are not statistically different $(P<0.05)$.

The mean follicular size at the lower ovulation-inhibiting doses $(0.22$ or 0.42 $\mathrm{mg}$ ) was almost always greater than at the highest $(0.85 \mathrm{mg})$ dose. The minimal effective dose for ovulation inhibition in most animals in a group $(0.42 \mathrm{mg})$ produced the condition of greatest follicular development on a group basis with a maximal incidence and size of follicles. A lower dose was associated with a decreased incidence of follicles of a larger size, and a higher dose was associated with high incidence but smaller follicle size.

Measurements at slaughter confirmed that ovaries of all treated groups had an increase in follicular fluid weight. Only the group receiving $0.22 \mathrm{mg}$ MGA daily failed to have a significant $(P<0.05)$ increase. The maximum ovarian weight after removal of the corpus luteum was in the puberal group receiving $0.44 \mathrm{mg}$ MGA daily. Differences between ovarian weights disappeared with removal of the corpus luteum and follicular fluid in Trial C. The differences in the weight of ovaries after slicing in Trial B would reflect the presence of a 
corpus luteum in control animals. There was also an effect of slaughter date (or days ALF) on follicular fluid from the largest follicle and an interesting effect on uterine weight in Trial C. The increase in follicular fluid from Days 1 to 3 after the last feed (ALF), followed by a decline to Day 8, represented follicular enlargement followed by ovulation. While there was no significant overall effect of treatment on uterine weight, there was a significant $(P<0.05)$ interaction of

TABLE 6

POST-TREATMENT REPRODUCTIVE PERFORMANCE OF HEIFERS FOLIOWING LONG-TERM TREATMENT WITH ORAL MGA

\begin{tabular}{|c|c|c|c|c|c|c|c|c|}
\hline \multirow{2}{*}{$\begin{array}{l}\text { MGA } \\
\text { dose }\end{array}$} & \multirow{2}{*}{$\begin{array}{c}\text { Days* } \\
\text { ALF to } \\
\text { slaughter }\end{array}$} & \multirow{2}{*}{$\begin{array}{l}\text { No. of } \\
\text { heifers }\end{array}$} & \multicolumn{2}{|c|}{ From 2 to 7 days ALF } & \multirow{2}{*}{$\begin{array}{c}\text { With } \\
\text { regressed } \\
\text { C.L. }(\%)\end{array}$} & \multirow{2}{*}{$\begin{array}{l}\text { Weight } \\
\text { of } \\
\text { uterus } \ddagger\end{array}$} & \multicolumn{2}{|c|}{$\begin{array}{c}\text { Follicular fuid } \\
\text { weight }(\mathrm{g})\end{array}$} \\
\hline & & & $\begin{array}{c}\text { In oestrus } \\
(\%)\end{array}$ & $\begin{array}{c}\text { Ovulated } \\
(\%)\end{array}$ & & & $\begin{array}{l}\text { Largest } \\
\text { follicle } \$\end{array}$ & Total T \\
\hline $0 \cdot 0$ & $\begin{array}{l}1 \\
3 \\
8\end{array}$ & $\begin{array}{l}6 \\
6 \\
6\end{array}$ & $\begin{array}{r}\overline{0} \\
50\end{array}$ & $\begin{array}{r}\overrightarrow{0} \\
50\end{array}$ & $\begin{array}{l}100 \\
100 \\
100\end{array}$ & $\begin{array}{l}150 \\
143 \\
139\end{array}$ & $\begin{array}{l}0.86 \\
0.97 \\
1.04\end{array}$ & $\begin{array}{l}1 \cdot 33 \\
2 \cdot 19 \\
2 \cdot 06\end{array}$ \\
\hline Total & & 18 & & & 100 & 144 & 0.95 & $1 \cdot 86$ \\
\hline 0.22 & $\begin{array}{l}1 \\
3 \\
8\end{array}$ & $\begin{array}{l}6 \\
6 \\
6\end{array}$ & $\begin{array}{l}5 \overline{0} \\
33\end{array}$ & $\begin{array}{l}-\overline{3} \\
33\end{array}$ & $\begin{array}{r}83 \\
50 \\
100\end{array}$ & $\begin{array}{l}150 \\
152 \\
143\end{array}$ & $\begin{array}{l}2 \cdot 10 \\
2 \cdot 36 \\
1.51\end{array}$ & $\begin{array}{l}3 \cdot 21 \\
3.98 \\
2 \cdot 54\end{array}$ \\
\hline Total & & 18 & & & 78 & 148 & 1.99 & $3 \cdot 24$ \\
\hline 0.44 & $\begin{array}{l}1 \\
3 \\
8\end{array}$ & $\begin{array}{l}6 \\
6 \\
6\end{array}$ & $\begin{array}{r}\overline{0} \\
83\end{array}$ & $\begin{array}{r}\overline{0} \\
67\end{array}$ & $\begin{array}{r}33 \\
17 \\
0\end{array}$ & $\begin{array}{l}139 \\
150 \\
121\end{array}$ & $\begin{array}{l}2 \cdot 46 \\
4 \cdot 64 \\
2 \cdot 99\end{array}$ & $\begin{array}{l}4 \cdot 01 \\
6 \cdot 38 \\
4 \cdot 95\end{array}$ \\
\hline Total & & 18 & & & 17 & 137 & $3 \cdot 36$ & $5 \cdot 11$ \\
\hline 0.85 & $\begin{array}{l}1 \\
3 \\
8\end{array}$ & $\begin{array}{l}6 \\
6 \\
6\end{array}$ & $\begin{array}{r}\overline{0} \\
50\end{array}$ & $\begin{array}{r}- \\
0 \\
50\end{array}$ & $\begin{array}{l}0 \\
0 \\
0\end{array}$ & $\begin{array}{l}176 \\
185 \\
120\end{array}$ & $\begin{array}{l}3.48 \\
3.54 \\
2.02\end{array}$ & $\begin{array}{l}4 \cdot 59 \\
4 \cdot 34 \\
3 \cdot 31\end{array}$ \\
\hline Total & & 18 & & & 0 & 160 & 3.01 & 4.08 \\
\hline $0.42 \dagger$ & $\begin{array}{l}1 \\
3 \\
8\end{array}$ & $\begin{array}{l}6 \\
6 \\
6\end{array}$ & $\begin{array}{r}\overline{0} \\
50\end{array}$ & $\begin{array}{r}\overline{0} \\
67\end{array}$ & $\begin{array}{r}17 \\
0 \\
33\end{array}$ & $\begin{array}{l}146 \\
172 \\
119\end{array}$ & $\begin{array}{l}2 \cdot 69 \\
4.00 \\
1.93\end{array}$ & $\begin{array}{l}4 \cdot 20 \\
5 \cdot 17 \\
3 \cdot 70\end{array}$ \\
\hline Total & & 18 & & & 17 & 146 & $2: 87$ & $4 \cdot 36$ \\
\hline
\end{tabular}

treatment with slaughter date. Gross observations made at slaughter are helpful in interpretation. The uteri of heifers treated with 0.42 to $0.85 \mathrm{mg}$ tended to have accumulations of very tenacious mucus, both in the uterine horns and in the cervix, particularly at Days 1 and 3. This was not true at Day 8, indicating that the return to oestrus was associated with a loss of this mucus. Thus, the uterine weights in certain treated groups were, respectively, similar, higher and lower than those of control heifers at Days 1, 3 and 8 ALF. The uterine weights of the two groups of spayed heifers were not significantly different from each other. The average uterine weight for control spayed 
heifers was $45 \mathrm{~g}$ compared with $61 \mathrm{~g}$ for spayed heifers receiving $0.42 \mathrm{mg}$ MGA daily and with $144 \mathrm{~g}$ for intact control heifers. The weight of the uterus and cervix of treated heifers in Trial B (245 g) was not different from that of control heifers $(255 \mathrm{~g})$.

Adrenal weights of heifers following long-term treatment were also obtained. In Trial $\mathrm{B}$, the left adrenal from treated heifers was significantly $(P<0.05)$ larger than from control heifers. In Trial C, the tendency was for adrenal weights to be similar for spayed control heifers, intact control heifers and for the heifers which were not puberal when treatment began. However, all groups of heifers which were puberal and receiving MGA had greater adrenal weights. The weight

TABLE 7

ADRENAL WEIGHTS OF HEIFERS FOLLOWING LONG-TERM ORAL MGA TREATMENT

\begin{tabular}{|c|c|c|c|c|c|}
\hline \multirow[b]{2}{*}{ Trial } & \multirow[b]{2}{*}{ MGA dose } & \multicolumn{4}{|c|}{ Glands wt $(\mathrm{g})$} \\
\hline & & Left & Right & Total $(g)$ & $\begin{array}{l}\text { Per } 100 \mathrm{lb} \\
\text { carcass wt }\end{array}$ \\
\hline B & $\begin{array}{l}0 \dagger^{\dagger} \\
0 \cdot 50 \dagger \\
D^{\top}\end{array}$ & $\begin{array}{c}9 \cdot 20 \\
10 \cdot 58^{*} \\
0.92\end{array}$ & $\begin{array}{l}8 \cdot 62 \\
9 \cdot 54 \\
1.00\end{array}$ & $\begin{array}{l}- \\
- \\
-\end{array}$ & $\begin{array}{l}- \\
-\end{array}$ \\
\hline C & $\begin{array}{l}0+ \\
0 \cdot 42+ \\
0 \dagger \\
0 \cdot 22 \dagger \\
0 \cdot 44 \dagger \\
0 \cdot 85 \dagger \\
0 \cdot 42 \$ \\
D \uparrow\end{array}$ & $\begin{array}{c}8 \cdot 82^{\mathrm{a}, \mathrm{b}} \\
8 \cdot 27^{\mathrm{a}} \\
8 \cdot 89^{\mathrm{a}, \mathrm{b}} \\
10 \cdot 16^{\mathrm{b}} \\
10 \cdot 02^{\mathrm{b}} \\
10 \cdot 16^{\mathrm{b}} \\
9 \cdot 04^{\mathrm{a}}, \mathrm{b} \\
1 \cdot 48\end{array}$ & $\begin{array}{l}7 \cdot 91^{\mathrm{a}} \\
7 \cdot 72^{\mathrm{a}} \\
8 \cdot 37^{\mathrm{a}}, \mathrm{b}, \mathrm{c} \\
9 \cdot 70^{\mathrm{c}} \\
9 \cdot 39^{\mathrm{b}, c} \\
9 \cdot 14^{\mathrm{a}}, \mathrm{b}, \mathrm{c} \\
8 \cdot 13^{\mathrm{a}}, \mathrm{b} \\
1 \cdot 46\end{array}$ & $\begin{array}{l}16 \cdot 73^{\mathrm{a}, \mathrm{b}} \\
15 \cdot 99^{\mathrm{a}} \\
17 \cdot 26^{\mathrm{a}} \mathrm{b}, \mathrm{c} \\
19 \cdot 86^{\mathrm{c}} \\
19 \cdot 41^{\mathrm{b}, \mathrm{c}} \\
19 \cdot 30^{\mathrm{b}, \mathrm{c}} \\
17 \cdot 17^{\mathrm{a}, \mathrm{b}} \mathrm{c} \\
2 \cdot 85\end{array}$ & $\begin{array}{l}3 \cdot 11 \\
2 \cdot 96 \\
3.05 \\
3 \cdot 39 \\
3 \cdot 30 \\
3 \cdot 34 \\
3 \cdot 15 \\
0.47\end{array}$ \\
\hline
\end{tabular}

* Significantly $(P<0.05)$ different from untreated controls.

$\uparrow$ Puberal heifers with ovaries intact.

* Puberal heifers which were spayed prior to treatment.

$\$$ Heifers were not puberal when treatment started.

Tा $\mathrm{D}=$ Magnitude of difference required for statistical significance $(P<0.05)$.

(a to c) All means bearing the same superscript are not statisticaliy different $(P<0.05)$.

was significantly $(P<0.05)$ greater only in the left adrenal gland when compared to intact puberal controls. It was found that an expression of adrenal weight in relation to carcass weight tended to reduce these differences. Comparison of the puberal spayed and puberal intact heifers receiving 0.42 to $0.44 \mathrm{mg}$ MGA daily indicates that the increased adrenal weight was associated with the presence of ovaries. This level of MGA tended to decrease adrenal weight in spayed heifers and tended to increase adrenal weight in intact heifers. There was no effect of slaughter date on adrenal weight.

\section{DISCUSSION}

The inhibition of ovulation by MGA in heifers was associated with an increase in both the incidence and size of palpable follicles. This finding does not necessarily mean that MGA stimulates gonadotrophin (FSH) release but, rather, may simply reflect an opportunity for the same level of FSH to act on a given 
follicle for a longer time than would ordinarily occur. MGA may prevent a release of $\mathrm{LH}$ in quantities needed for ovulation but may allow low levels of LH to be released for synergism with FSH. The increase in follicular fluid in the largest follicle accounted almost wholly for the increase in total follicular fluid from both ovaries. These enlarged follicles persisted on the ovaries for a time and some eventually might regress to be replaced with another follicle, while some ovulated at the first oestrous period following the end of MGA treatment.

That these enlarged follicles are functionally active may be deduced from several indications of oestrogen production, namely, swelling of external genitalia, frequent discharge of mucus through the vulva, an increase in ferning pattern of the cervical mucus and an increased adrenal weight. An increase in adrenal weights of heifers has been reported in association with diethylstilboestrol treatment (Clegg \& Cole, 1954). These indications of increased follicular size and oestrogenic status during a period of MGA treatment suggests that MGA treatment did not simulate the corpus luteum in the means by which ovulation was inhibited. The data presented here do not eliminate the possibility that the level of progestagen may account for this difference. However, a level of MGA (0.85 mg daily) twice that which gave nearly complete inhibition of ovulation also allowed increased follicular development. Such findings appear to suggest that the influence of MGA was more on release of ovulating hormone ( $\mathbf{L H}$ ) from the pituitary gland than on that of folliclestimulating hormone.

The increase in adrenal weight due to treatment with MGA contrasts with the decrease reported in rats (Duncan, Lyster, Hendrix, Clark \& Webster, 1964) but the results in spayed heifers do tend to suggest that effects on adrenal size might occur in cattle under other circumstances.

The demonstration of the effects of MGA on follicle size, oestrogenic status and uterine weights might be related to the somewhat lower conception rate at the synchronized oestrus following administration of various progestagens (Lamond, 1964). These data would seem to indicate the potential complexity of determining the immediate cause of reduced fertility.

\section{ACKNOWLEDGMENTS}

The authors wish to acknowledge the advice of R. E. Bloss in the design of experiments and the assistance of J. I. Northam in statistical analyses of certain data. The additional supplies of melengestrol acetate were supplied by J. A. Campbell and B. A. Johnson of the Biochemical Research Division.

\section{REFERENCES}

Alliston, C. W., Patterson, T. B. \& Ulberg, L. G. (1958) Grystallization patterns of cervical mucus as related to estrus in beef cattle. F. Anim. Sci. 17, 322.

Clegg, M. T. \& Cole, H. H. (1954) The action of stilbestrol on the growth response in ruminants. 7. Anim. Sci. 13, 108.

Duncan, G. W., Lyster, S. G., Hendrix, J. W., Glark, J. J. \& Webster, H. D. (1964) Biologic effects of melengestrol acetate. Fert. Steril. 15, 419.

LAmond, D. R. (1964) Synchronization of ovarian cycles in sheep and cattle. Anim. Breed. Abstr. 32, 269. Snedecor, G. W. (1956) Statistical methods, 5th edn., p. 251. Iowa State College Press, Ames.

Zimbelman, R. G. \& Sмith, L. W. (1966) Control of ovulation in cattle with melengestrol acetate. I. Effect of dosage and route of administration. F. Reprod. Fert. 11, 185. 